\title{
Escherichia coli expression and purification of four antimicrobial peptides fused to a family 3 carbohydrate-binding module (CBM) from Clostridium thermocellum
}

\author{
Catarina I.P.D. Guerreiro ${ }^{a}$, Carlos M.G.A. Fontes ${ }^{a}$, Miguel Gama ${ }^{b}$, Lucília Domingues ${ }^{b, *}$ \\ ${ }^{a}$ CIISA, Faculdade de Medicina Veterinária, Pólo Universitário da Ajuda, Avenida da Universidade Técnica, 1300-477 Lisboa, Portugal \\ ${ }^{\mathrm{b}}$ IBB-Institute for Biotechnology and Bioengineering, Centre of Biological Engineering, Universidade do Minho, \\ Campus de Gualtar, 4710-057 Braga, Portugal
}

Received 3 December 2007, and in revised form 24 January 2008

Available online 5 February 2008

\begin{abstract}
Antimicrobial peptides (AMPs) are molecules that act in a wide range of physiological defensive mechanisms developed to counteract bacteria, fungi, parasites and viruses. Several hundreds of AMPs have been identified and characterized. These molecules are presently gaining increasing importance, as a consequence of their remarkable resistance to microorganism adaptation. Carbohydrate-binding modules (CBMs) are non-catalytic domains that anchor glycoside hydrolases into complex carbohydrates. Clostridium thermocellum produces a multi-enzyme complex of cellulases and hemicellulases, termed the cellulosome, which is organized by the scaffoldin protein CipA. Binding of the cellulosome to the plant cell wall results from the action of CipA family 3 CBM (CBM3), which presents a high affinity for crystalline cellulose. Here CipA family 3 CBM was fused to four different AMPs using recombinant DNA technology and the fusion recombinant proteins were expressed at high levels in Escherichia coli cells. CBM3 does not present antibacterial activity and does not bind to the bacterial surface. However, the four recombinant proteins retained the ability to bind cellulose, suggesting that CBM3 is a good candidate polypeptide to direct the binding of AMPs into cellulosic supports. A comprehensive characterization of the antimicrobial activity of the recombinant fusion proteins is currently under evaluation.
\end{abstract}

(c) 2008 Elsevier Inc. All rights reserved.

Keywords: Cationic amphiphilic antimicrobial peptides; PMAP-23; CBM3; Protein fusion; Clostridium thermocellum; Escherichia coli

AMPs are cationic molecules with a wide range of antimicrobial activities, which vary from bacteria to fungi, parasites and viruses. These molecules have been recognized as an important component of the non-specific host defense system and innate immunity of all animal classes, including insects, amphibians and mammals [1]. Several hundreds of AMPs have already been identified and characterized (http://www.bbcm.units.it/ tossi). These molecules represent very appealing new tools for fighting infection, since microorganisms do not easily develop resistance mechanisms against their mode of action as it has been described for other types of antimicrobial compounds. This is prob-

\footnotetext{
* Corresponding author. Fax: +351 253678986.

E-mail address: luciliad@deb.uminho.pt (L. Domingues).
}

ably due to the particular capacity of AMPs to bind and disrupt cellular membranes. It is well recognized that mutations in the genetic information encoding the overall plasma membrane structure and which may counteract the action of AMPs are less likely to occur than variations in the enzyme physiology within a host cell [2].

In early studies involving AMPs, these molecules were obtained through purification from their original hosts or by chemical synthesis. This, of course, presented many restrictions to AMPs research mainly in what concerned the production of detectable quantities of the peptides. In recent years, many small cationic AMPs have been successfully produced using recombinant DNA methods in heterologous hosts [3-6], allowing the purification of larger quantities of the recombinant proteins. It is presently rec- 
ognized that producing cationic AMPs using recombinant techniques will accelerate research on their pharmaceutical potential and potential clinical application [6]. Many host cells have been selected for expression of AMPs but Escherichia coli has been established as one of the most popular recombinant bioreactors due to its fast growth rate and well-established expression systems [6]. Since AMPs are usually very small to be produced effectively individually, many authors aimed to express them in fusion with other molecules [3,6-8]. Problems concerning low levels of expression, poor solubility, toxicity for the host cell, product proteolysis and poor recovery yields are usually overcome by the implementation of the fusion technology [9].

Carbohydrate-binding modules $(\mathrm{CBMs})^{1}$ are non-catalytic domains present in glycoside hydrolases which target the associated catalytic modules to their substrates, therefore potentiating enzyme activity. Based on primary structure similarity, CBMs have been grouped into 50 sequence-based families (http://afmb.cnrs-mrs.fr/CAZY; February 2008). Structural studies on representatives of the majority of CBM families demonstrate that the topology of CBM ligand-binding sites complements the conformation of the target polysaccharide. Thus, in Type A modules, which interact with the flat surfaces of crystalline polysaccharides, such as cellulose, the binding site comprises a planar hydrophobic platform that contains three exposed aromatic amino acids [10]. In contrast, Type B CBMs, which bind to single polysaccharide chains, accommodate the ligands within extended clefts of varying depths [10]. In general, the capacity of CBMs to specifically recognize a range of polysaccharides has been shown to be pivotal in a range of biotechnological applications [11].

The development of mechanisms for targeting bio-molecules to a diversity of matrixes is an emerging theme in biochemistry and biotechnology. In this work four different AMPs were fused to a family 3 CBM of CipA, a nonhydrolytic structural protein responsible for the assembly of Clostridium thermocellum multi-enzyme complex of cellulases and hemicellulases, termed the cellulosome [12]. The major goal of this approach was not only to promote the levels of expression of the selected AMPs in E. coli but also to develop a biotechnological tool that would allow fixing a variety of polypeptides, such as AMPs, onto cellulosic surfaces. Therefore, the immobilization of these fusion proteins in cellulosic supports will allow the generation of novel bio-products possessing antimicrobial properties. Cellulose is a safe and inert macromolecule and has excellent physical properties. In addition, it is cheap and commercially available in many different forms and has been approved for many pharmaceutical and human uses [11].

\footnotetext{
${ }^{1}$ Abbreviations used: AMPs, antimicrobial peptides; CBMs, carbohydrate-binding modules; LK, linker sequence; PCR, polymerase chain reaction; LB, Luria-Bertani broth; IPTG, isopropyl- $\beta$-D-thiogalactopyranoside; IMAC, immobilized metal ion affinity chromatography.
}

\section{Materials and methods}

\section{Cloning of the DNA sequence of CBM3 with a N-terminal linker}

The gene encoding CBM3 fused to the endogenous CipA N-terminal linker sequence (LK) was isolated through PCR. The inclusion of the linker region in the encoding DNA sequence was envisaged to improve flexibility in the resulting fusion proteins. The DNA fragment encoding CBM3 and its N-terminal LK from $C$. thermocellum was amplified by polymerase chain reaction (PCR) from $C$. thermocellum YS genomic DNA with the thermostable DNA polymerase $P f u$ Turbo (Stratagene). The primers used were 5'-ACACCGACCAAGGGAGCAACA-3' (forward primer) and 5'-TTCTTTACCCCATACAAG AAC-3' (reverse primer). PCR was performed as follows: preheating at $95^{\circ} \mathrm{C}$ for $3 \mathrm{~min}, 25$ cycles at $95^{\circ} \mathrm{C}$ for $20 \mathrm{~s}$, $55^{\circ} \mathrm{C}$ for $30 \mathrm{~s}$ and $72{ }^{\circ} \mathrm{C}$ for $30 \mathrm{~s}$, followed by a final elongation period at $72{ }^{\circ} \mathrm{C}$ for $10 \mathrm{~min}$. The amplified product was recovered from a $1 \%$ agarose gel using the Gel Band Purification Kit (GE Health) and ligated into pMOSBlue (GE Health) to generate pCG1. The DNA insert of pCG1 was sequenced to ensure that no mutations had occurred during the PCR. This plasmid was used as template for the subsequent amplifications aiming at generating the fusion genes.

\section{Cloning of the DNA sequences encoding the fusion proteins}

For these studies four cationic and amphiphilic peptides were selected: peptide-1 (LKLLKKL), peptide-2 (LKLL KKLLKLLKKLGGGK), peptide-3 (LKKLLKKLKKL LKK) and porcine myeloid antibacterial peptide-23 (PMAP-23) (RIIDLLWRVRRPQKPKFVTVWVR) [13], as depicted in Table 1. The nucleotide sequence of each peptide was engineered to allow codon optimization in E. coli. Sequences encoding the four peptides were included in the primers and fusion genes were generated through PCR, using the DNA polymerase FideliTaq (GE Health), utilizing plasmid pCG1 as template. The sequences of the primers used in this study for this particular aim are shown in Table 2. Primers included NheI and XhoI restriction sites. To allow the sub-cloning of the gene encoding CBM3 fused to the linker sequence (LK-CBM3) into the expression vector, the DNA sequence encoding this truncated version of CipA was also amplified by PCR (Table 2). The PCR reactions were performed as follows: preheating at $95{ }^{\circ} \mathrm{C}$ for $2 \mathrm{~min}, 25$ cycles at $95^{\circ} \mathrm{C}$ for $30 \mathrm{~s}, 55^{\circ} \mathrm{C}$ for $30 \mathrm{~s}$ and $68^{\circ} \mathrm{C}$ for $1 \mathrm{~min}$, followed by a final elongation period of $68{ }^{\circ} \mathrm{C}$ for $5 \mathrm{~min}$. Amplified fragments were recovered from a $1 \%$ agarose gel using the Qiagen Gel Extraction Kit (Qiagen), ligated into plasmid pMOSBlue and sequenced to ensure that no mutations had occurred during the PCR. The generated recombinant plasmids were digested with NheI and XhoI and the excised products were cloned into expression vector pET21a (Novagen), pre- 
Table 1

Primary sequence of antimicrobial peptides used for fusion with a family 3 CBM

\begin{tabular}{lcll}
\hline Antimicrobial peptide & No. of residues & Primary sequence & References \\
\hline Peptide-1 & 7 & LKLLKKL & \\
Peptide-2 & 18 & LKLLKKLLKLLKKLGGGK & \\
Peptide-3 & 14 & LKKLLKKLKKLLKK & {$[16]$} \\
PMAP-23 & 23 & RIIDLLWRVRRPQKPKFVTVWVR & {$[13]$} \\
\hline
\end{tabular}

Table 2

Primers used for cloning the DNA sequences encoding various AMPs in fusion with the gene of a family $3 \mathrm{CBM}$

\begin{tabular}{lll}
\hline Construct & Primers & Sequence $\left(5^{\prime}-3^{\prime}\right)$ \\
\hline Peptide-1-LK-CBM3 & Forward & CTCGCTAGCCTGAAACTGCTGAAAAAACTGACACCGACCAAGGGAGCA \\
& Reverse & CACCTCGAGTTCTTTACCCCATACAAGAAC \\
Peptide-2-LK-CBM3 & Forward & CTCGCTAGCCTGAAACTGCTGAAAAAACTGCTGAAACTGCTGAAAAAACT \\
& GGGTGGTGGTAAAACACCGACCAAGGGAGCA \\
& CACCTCGAGTTCTTTACCCCATACAAGAAC \\
Peptide-3-LK-CBM3 & Forward & CTCGCTAGCCTGAAAAAACTGCTGAAAAAACTGAAAAAACTGCTGAAAAA \\
& AACACCGACCAAGGGAGCA \\
PMAP-23-LK-CBM3 & CACCTCGAGTTCTTTACCCCATACAAGAAC \\
& Forward & CTCGCTAGCCGTATTATTGATCTGCTGTGGCGTGTGCGTCGTCCGCAGAAA \\
& CCGAAATTTGGACCGTGTGGGTGCGTACACCGACCAAGGGAGCA \\
LK-CBM3 & CACCTCGAGTTCTTTACCCCATACAAGAAC \\
& CTCGCTAGCACACCGACCAAGGGAGCA \\
& Forward & CACCTCGAGTTCTTTACCCCATACAAGAAC \\
\hline
\end{tabular}

a The NheI and XhoI restriction sites introduced in the forward and reverse primers, respectively, are shown in bold.

viously digested with the same restriction enzymes. This vector carries a T7lac promotor and the resulting recombinant proteins contained a C-terminal $\mathrm{His}_{6}$-tag to facilitate purification.

\section{Expression of recombinants $L K-C B M$ and fused proteins}

To optimize expression of the various recombinant proteins, different growing and induction conditions were tested for a variety of recombinant $E$. coli strains. Below is a description of the optimized growing conditions obtained that allow the expression of each specific protein. To express peptide-1 fused to LK-CBM3 (peptide-1-LKCBM3) and peptide-3 fused to LK-CBM3 (peptide-3-LKCBM3), E. coli Tuner (DE3) (Novagen) cells harboring the appropriate recombinant plasmids were cultured in Luria-Bertani broth (LB) containing $100 \mu \mathrm{g} / \mathrm{mL}$ ampicillin at $37^{\circ} \mathrm{C}$ to mid-exponential phase $\left(\mathrm{OD}_{595}=0.6\right)$. At this point isopropyl- $\beta$-D-thiogalactopyranoside (IPTG) was added to a final concentration of $0.2 \mathrm{mM}$ and the cultures were incubated at $18{ }^{\circ} \mathrm{C}$ and $30^{\circ} \mathrm{C}$ for $16 \mathrm{~h}$, respectively. The proteins LK-CBM3 and PMAP-23-LK-CBM3, which results from the fusion of LK-CBM3 with PMAP-23, were expressed in E. coli BL21 (DE3) (Novagen) cells harboring the appropriate recombinant plasmids and cultured in LB containing $100 \mu \mathrm{g} / \mathrm{mL}$ ampicillin at $37^{\circ} \mathrm{C}$ to mid-exponential phase $\left(\mathrm{OD}_{595}=0.6\right)$. At this point IPTG was added to a final concentration of $1 \mathrm{mM}$ and the cultures were incubated at $37^{\circ} \mathrm{C}$ for further $4 \mathrm{~h}$. Peptide- 2 in fusion with
LK-CBM3 (peptide-2-LK-CBM3) was found to be insoluble when expressed by different $E$. coli strains under a range of induction conditions, which included inducing temperatures varying from $16{ }^{\circ} \mathrm{C}$ to $37^{\circ} \mathrm{C}$ and IPTG concentrations ranging from $0.01 \mathrm{mM}$ to $1 \mathrm{mM}$.

\section{Purification of recombinant proteins}

Recombinant $E$. coli cells were harvested by centrifugation at $7000 \mathrm{~g}$ at $4{ }^{\circ} \mathrm{C}$ for $15 \mathrm{~min}$, resuspended in $20 \mathrm{mM}$ Tris- $\mathrm{HCl} \mathrm{pH}$ 7.0, $20 \mathrm{mM} \mathrm{NaCl}, 5 \mathrm{mM} \mathrm{CaCl}{ }_{2}\left(2 \mathrm{H}_{2} \mathrm{O}\right)$ (Buffer A) and disrupted by sonication on ice for $12 \mathrm{~min}$. The resulting cell-free extracts were collected by centrifugation at $20,440 \mathrm{~g}$ at $4{ }^{\circ} \mathrm{C}$ for $30 \mathrm{~min}$ and the $\mathrm{His}_{6}$-tagged recombinant proteins purified by immobilized metal ion affinity chromatography (IMAC), using $5 \mathrm{~mL}$ Niquel Hi-Trap Columns (GE Health). The column charged with $0.1 \mathrm{M} \mathrm{NiSO}_{4}$ was equilibrated with $20 \mathrm{mM} \mathrm{Na}_{3} \mathrm{PO}_{4}, 500 \mathrm{mM} \mathrm{NaCl}$, $40 \mathrm{mM}$ Imidazole, $\mathrm{pH}$ 7.4. The cell extracts were loaded into the column which was washed with the equilibration buffer. Finally the recombinant proteins were eluted with $20 \mathrm{mM} \mathrm{Na} \mathrm{PO}_{4}, 500 \mathrm{mM} \mathrm{NaCl}, 300 \mathrm{mM}$ Imidazole, $\mathrm{pH}$ 7.4. After purification, proteins buffer were exchanged into Buffer A, using PD10-columns (GE Health). Purified proteins were analyzed by mass spectrometry and SDS-PAGE using $12 \%(\mathrm{w} / \mathrm{v})$ acrylamide gels. Predicted sizes for the recombinant proteins were $22.1 \mathrm{kDa}$ for LK-CBM3, 23.0 kDa for peptide-1-LK-CBM3, 24.1 kDa for peptide- 
2-LK-CBM3， $23.8 \mathrm{kDa}$ for peptide-3-LK-CBM3 and 25.1 kDa for PMAP-23-LK-CBM3.

\section{Binding assays}

Qualitative assessment of the binding of the recombinant proteins to Avicel (Sigma) was developed as follows: $100 \mu \mathrm{g}$ of LK-CBM3, $50 \mu \mathrm{g}$ of peptide-1-LK-CBM3, $50 \mu \mathrm{g}$ of peptide-3-LK-CBM3 and $50 \mu \mathrm{g}$ of PMAP-23LK-CBM3, all in Buffer A, with 1\% (v/v) Tween 20, were mixed with $4 \mathrm{mg}$ of Avicel in a final reaction volume of $200 \mu \mathrm{L}$. The mixture was incubated for $1 \mathrm{~h}$ at $30^{\circ} \mathrm{C}$ with vigorous shaking. The insoluble ligand was collected by centrifugation at $13,000 \mathrm{~g}$ at room temperature for $10 \mathrm{~min}$. The supernatant, containing the unbound fraction, was recovered and the resulting pellet was washed four times with $400 \mu \mathrm{L}$ Buffer A and $20 \mu \mathrm{L} \mathrm{1 \% (v/v)} \mathrm{Tween}$ 20. Finally the carbohydrate pellet was resuspended in $100 \mu \mathrm{L} 10 \%$ (w/v) SDS and $25 \mu \mathrm{L} 5 \times$ SDS sample buffer. Bound and unbound fractions were analyzed by SDSPAGE using a $12 \%(\mathrm{w} / \mathrm{v})$ acrylamide gel. Controls containing protein but no polysaccharide were performed in parallel to ensure that no precipitation of the recombinant proteins occurred during the experiment (data not shown).

\section{Antimicrobial assay}

An antimicrobial assay for assessing the antibacterial properties of LK-CBM3 was implemented based on the procedures described in reference [14]. Briefly, $100 \mathrm{~mL}$ of LB were inoculated with colonies from an overnight culture plate of E. coli XL10 Gold (Stratagene) and grown at $37^{\circ} \mathrm{C}$ until $\mathrm{OD}_{600}=0.5$. The cells $(1 \mathrm{~mL})$ were recovered by centrifugation at $3000 \mathrm{~g}$ at $10^{\circ} \mathrm{C}$ for $10 \mathrm{~min}$ and the supernatant discarded. Cells were washed twice with $1 \mathrm{~mL}$ of Buffer A. Finally, bacteria were resuspended in $1 \mathrm{~mL}$ of the same buffer and serially diluted until $10^{-4}$. Precisely $150 \mu \mathrm{L}$ of E. coli XL10 Gold $10^{-4}$ were incubated with $150 \mu \mathrm{L} \mathrm{LK}$ CBM3 at three different protein concentrations $(0.1 \mathrm{mg} /$ $\mathrm{mL}, 1 \mathrm{mg} / \mathrm{mL}$, and $2 \mathrm{mg} / \mathrm{mL}$, all diluted in Buffer A). Several controls were incorporated in the experiment, including the incubation of the cells solely in Buffer A or with BSA at the same protein concentrations used for LK-CBM3. Cells were incubated under the various conditions at $210 \mathrm{rpm}$ in an orbital incubator at $37^{\circ} \mathrm{C}$ for $2 \mathrm{~h}$. At the end of the incubation period, $50 \mu \mathrm{L}$ of each sample were plated onto LB agar plates and the number of bacterial colonies formed was counted after a $16 \mathrm{~h}$ incubation at $37^{\circ} \mathrm{C}$. The remaining of the non-plated mixture was centrifuged at $13,000 \mathrm{~g}$ at $4{ }^{\circ} \mathrm{C}$ for $5 \mathrm{~min}$ and the supernatants used for protein quantitation using Bradford reagent [15] and analyzed by SDS-PAGE using a $14 \%(\mathrm{w} / \mathrm{v})$ acrylamide gel.

\section{Results and discussion}

\section{Expression and purification of recombinant $L K-C B M$ and fused proteins}

Four peptides, termed peptide-1, peptide-2, peptide- 3 and PMAP-23 [13], which details are presented in Table 1, were fused with the family $3 \mathrm{CBM}$ of CipA from $C$. thermocellum. The recombinant fusion proteins were engineered to contain an $\mathrm{N}$-terminal AMP domain and a C-terminal His $_{6}$-tag. Peptide-1, peptide-2, and peptide-3 are synthetic amphiphilic cationic peptides, which design was based on the studies provided by other authors [16,17]. Similar molecules have already proved to have potent antimicrobial activity against Gram negative and Gram positive bacteria [16]. It has also been previously shown that peptides composed of both hydrophobic and hydrophilic residues, such as leucine $(\mathrm{L})$ and lysine $(\mathrm{K})$, present antimicrobial activity against E. coli and Staphylococcus aureus, both in the soluble form or immobilized into a water-insoluble non-degradable polymer support [17]. These apparently simple cationic peptides with proven detectable antimicrobial activity were selected to fuse with $\mathrm{CtCBM}$. In addition, a different peptide with antimicrobial activity, termed PMAP-23, was also selected for fusion with the carbohydrate-binding module [13]. This peptide derives from porcine myeloid cells, is highly cationic and also tends to form an amphipathic structure, typical of other antibacterial peptides [1]. Synthetic PMAP-23 showed antibacterial activity against Gram positive and negative strains but no lytic activity against human erythrocytes, which
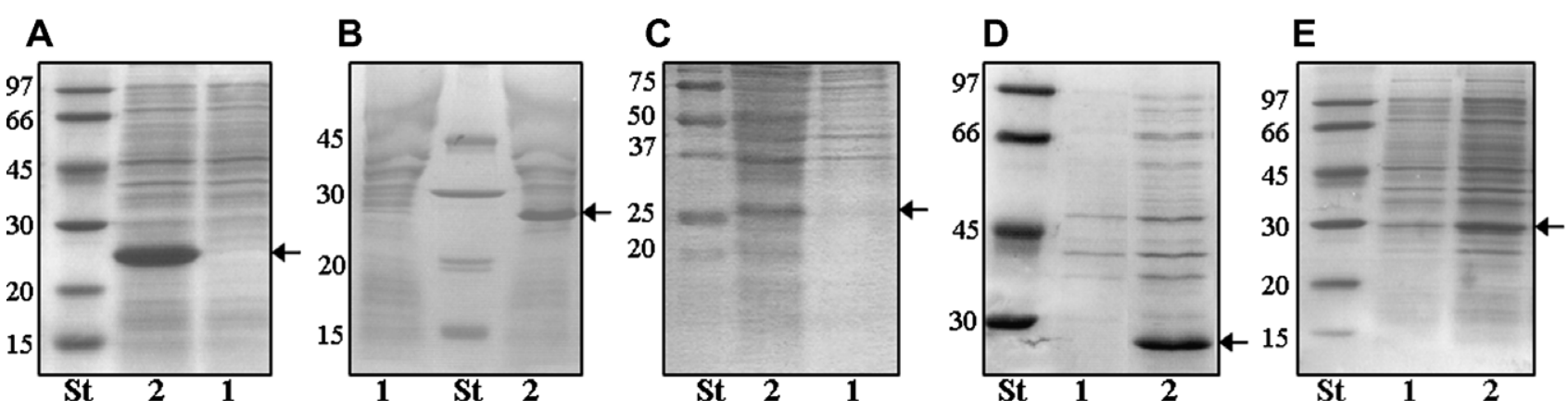

Fig. 1. Expression of the recombinant proteins LK-CBM3 (A), peptide-1-LK-CBM3 (B), peptide-2-LK-CBM3 (C), peptide-3-LK-CBM3 (D) and PMAP23-LK-CBM3 (E). Lanes: 1, uninduced cells; 2, cells induced with IPTG; St, molecular mass protein standards. Protein extracts of Lanes 1 and 2 result from the resuspention of the bacterial cells in Buffer A. Arrows highlight the position of each one of the recombinant proteins. 
suggested a certain degree of selectivity in disrupting cell membranes [1,13]. It has been suggested that PMAP-23 antibacterial activity results from the interaction of the peptide with the bacteria cell membrane, followed by bacteria membrane alteration $[1,13]$.

Data presented in Fig. 1 confirms that all four recombinant fusion proteins were expressed in E. coli. However, only peptide-1-LK-CBM3, peptide-3-LK-CBM3, PMAP23-LK-CBM3 and LK-CBM3 were expressed in the solu-

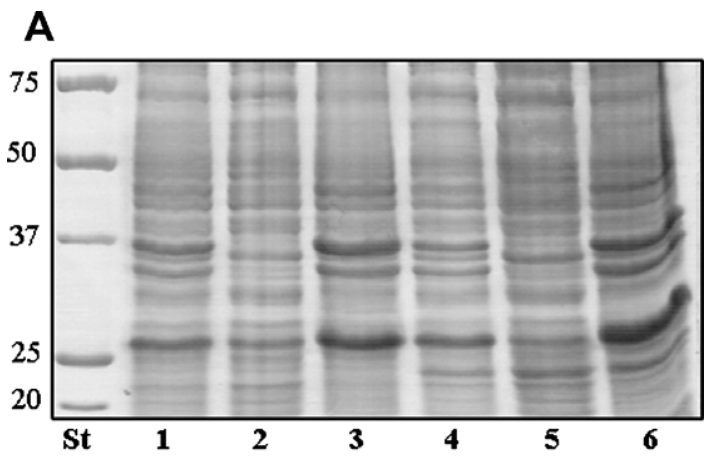

B

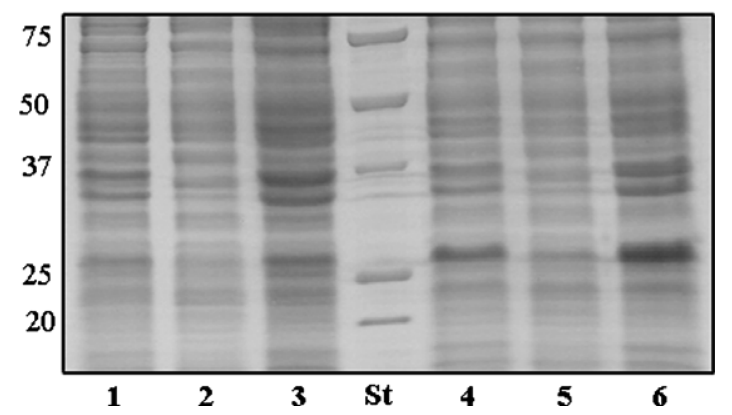

Fig. 2. Expression of recombinant peptide-2-LK-CBM3 in different E. coli strains grown under different growth and induction temperatures. (A) E. coli Tuner (lanes 1-3) and BL21 (DE3)pLysS (lanes 4-6) grown at $30^{\circ} \mathrm{C}$, induced at $30^{\circ} \mathrm{C}$. (B) BL21 (DE3)pLysS grown at $37^{\circ} \mathrm{C}$, induced at $18^{\circ} \mathrm{C}$ (lanes 1-3) and at $30^{\circ} \mathrm{C}$ (lanes 4-6). Lanes 1 and 4, cells induced with IPTG; lanes 2 and 5, soluble cell-free extract; lanes 3 and 6 , insoluble cell pellet; St, molecular mass protein standards. ble fraction of $E$. coli, although as a result of several optimization experiments (results not shown). In contrast, peptide-2-LK-CBM3 formed inclusion bodies in E. coli and protein precipitation in vivo was persistent while using different E. coli expression strains and different growth and induction temperatures (Figs. 2 and 3). To overcome the insolubility of some AMPs, as well as their cytotoxic properties, some authors expressed these peptides in E. coli in fusion with different protein partners, utilizing different expression systems. Therefore, SMAP-29 was expressed using the intein-mediated system [14], the human $\beta$-defen$\sin 2$ with the thioredoxin expression system [3,6], Hal18 by fusion with baculoviral polyhedron protein [9] and LL-37 utilizing the glutathione. S-transferase fusion system [7], among many other examples. In addition, enterocins A and B, which are bacteriocins from Enterococcus faecium, were produced in fusion with a microbial CBM, although the experiment aimed at developing an easier purification system for the recombinant proteins [18]. In general, the aim of these experiments was to develop a mechanism to produce at high levels the fusion protein in order to enhance the production of the AMP itself. Therefore, after purification of the fused proteins, a proteolytic digestion step using a specific protease is included in order to release the AMP in the purified form. In contrast with the above mentioned experiments, the aim of the work reported here was to obtain the AMPs fused with $\mathrm{CtCBM} 3$ as the final product. More than a mere fusion partner, CBM3 was used to target the AMP for cellulosic surfaces. Notwithstanding this major goal of the experiments, it can be anticipated that the expression and purification of the AMP fusion recombinant proteins was probably facilitated by the presence of CBM3 and the C-terminal $\mathrm{His}_{6}$-tag.

After optimizing expression in E. coli, the recombinant proteins were purified through IMAC. The data, presented in Fig. 4, demonstrate that all proteins were purified from most $E$. coli contaminants and were obtained at high concentrations. Following the purification step, the proteins were buffer exchanged into Buffer A and their concentration calculated. Purified proteins presented final concentrations
A

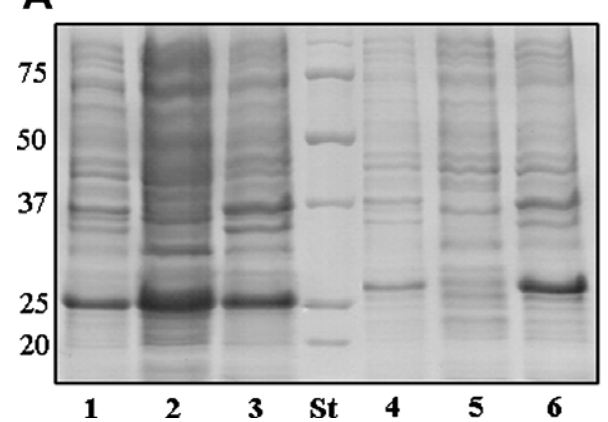

B

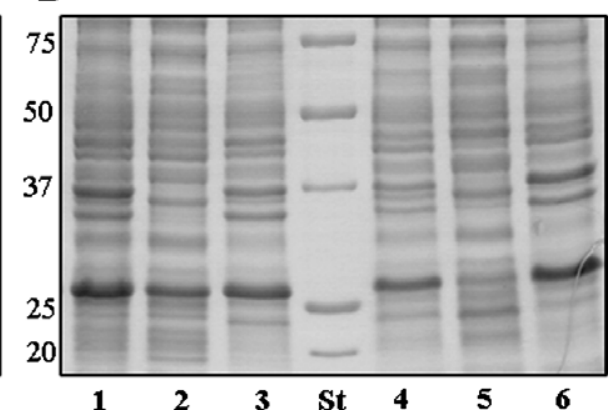

Fig. 3. Comparing the expression and solubility of recombinant peptide-2-LK-CBM3 with two other recombinant proteins expressed in E. coli Tuner. (A) peptide-1-LK-CBM3 (lanes 1-3) and peptide-2-LK-CBM3 (lanes 4-6) induced at $18{ }^{\circ} \mathrm{C}$. (B) peptide-3-LK-CBM3 (lanes 1-3) and peptide-2-LK-CBM3 (lanes 4-6) induced at $30^{\circ} \mathrm{C}$. Lanes 1 and 4, cells induced with IPTG; lanes 2 and 5, soluble cell-free extract; lanes 3 and 6, insoluble cell pellet; St, molecular mass protein standards. 
ranging from $0.5 \mathrm{mg} / \mathrm{mL}$ to $2.5 \mathrm{mg} / \mathrm{mL}$. Mass spectrometry analysis confirmed the expected sizes and, therefore, the integrity of the four recombinant proteins, suggesting that the N-terminal AMP domain was not subjected to proteolysis in E. coli and during the purification steps.

\section{Binding assays}

$\mathrm{Ct}$ CBM3 from CipA is a very well characterized and studied CBM [11,12] and its three-dimensional structure has already been elucidated [12]. It is a Type A CBM, which means that it possesses a planar surface that interacts tightly with crystalline cellulose. $\mathrm{CtCBM} 3$ equilibrium affinity constant $\left(K_{\mathrm{a}}\right)$ for Avicel was reported to be $7.7 \times 10^{6} \mathrm{M}^{-1}$ [11]. To investigate whether the fusion of each of the four AMPs to $\mathrm{CtCBM} 3$ had some effect on its capacity to interact with crystalline cellulose, the capacity of the recombinant proteins to bind Avicel was evaluated. The data, presented in Fig. 5, confirmed that all AMPs-LK-CBM3 retained capacity to bind Avicel, as revealed by the minor quantity of protein present in the unbound fraction and the resulting association of the recombinant protein with the carbohydrate fraction. Although a small quantity of LK-CBM3 was shown not to bind the structural carbohydrate (panel $\mathrm{A}$, lane $\mathrm{U}$ ), this phenomenon is certainly due to a relative excess of protein concentration in relation to the Avicel. In addition, the data also suggested that incorporation of
His $_{6}$-tag in the recombinant proteins had no effect in the capacity of the protein to bind cellulose. Taken together the results suggest that fusion of CBM3 with AMPs had no affect in cellulose-binding activity of the CBM, which makes the recombinant proteins potential candidates to target AMPs to cellulosic supports.

\section{Evaluating the antimicrobial activity of CBM3}

It has been reported that C-type lectins, another kind of carbohydrate-binding molecules, may present antimicrobial activity $[19,20]$. Like CBMs, lectins are proteins that recognize carbohydrates and fulfill an important role in the immune system, which has been extensively studied over the last years. Lectins are well described but the understanding of the mechanisms by which they influence the immune responses is not well defined. However, it is believed that lectins are involved in the recognition of carbohydrates at cell surfaces [21]. To find out whether the recombinant LK-CBM3 itself would present antibacterial activity, an assay was performed against $E$. coli XL10 Gold cells (Stratagene). BSA was incorporated in this experiment as a control protein which does not possess recognizable antimicrobial activity. Both proteins were used at three different concentrations: $0.1 \mathrm{mg} / \mathrm{mL}, 1 \mathrm{mg} /$ $\mathrm{mL}$, and $2 \mathrm{mg} / \mathrm{mL}$. The data, presented in Table 3, demonstrated that the numbers of $\mathrm{CFU} / \mathrm{mL}$ are in the same
A

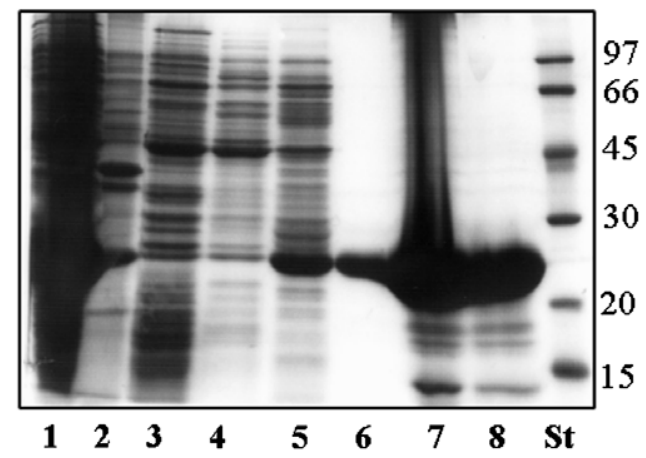

C

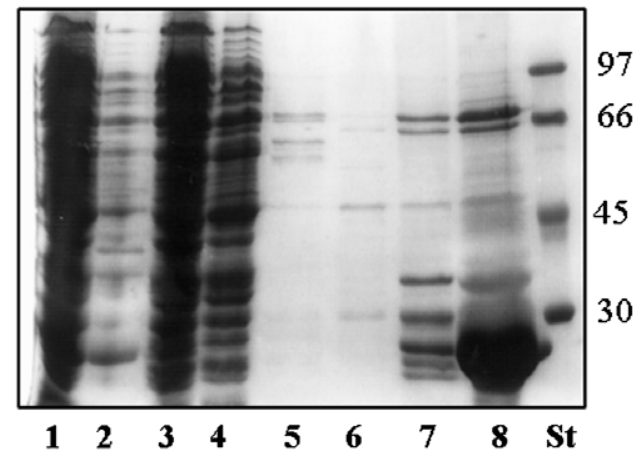

B

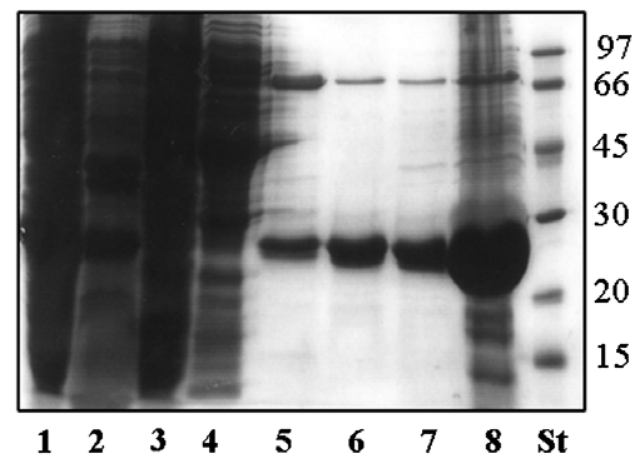

D

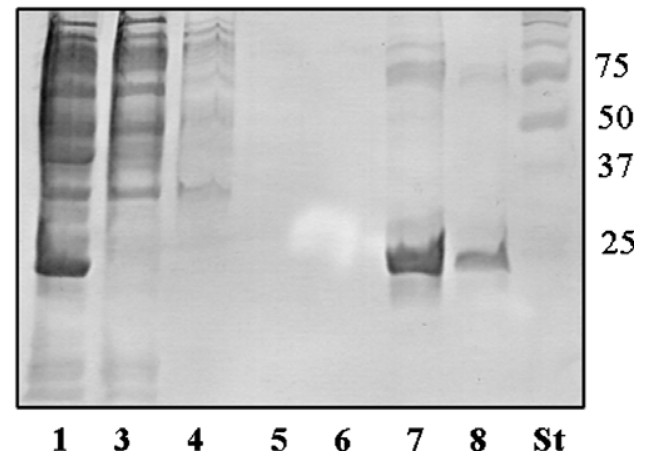

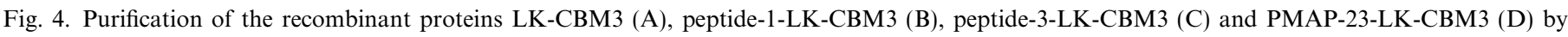

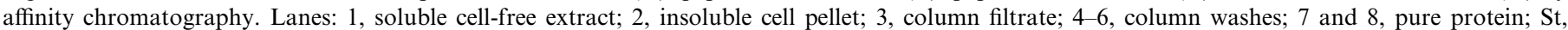
molecular mass protein standards. 
A

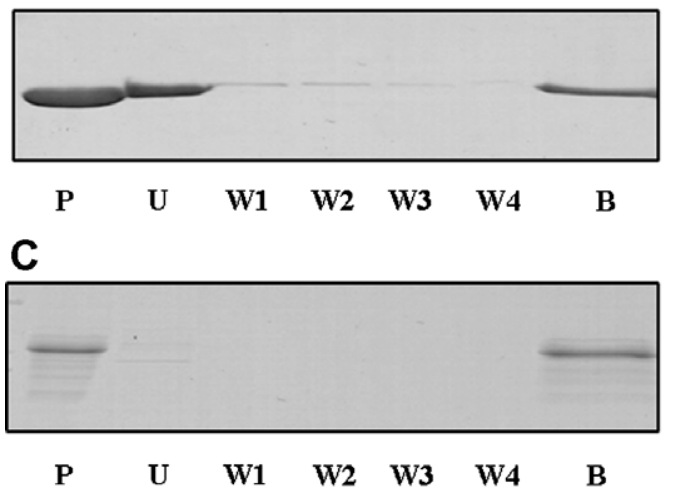

B

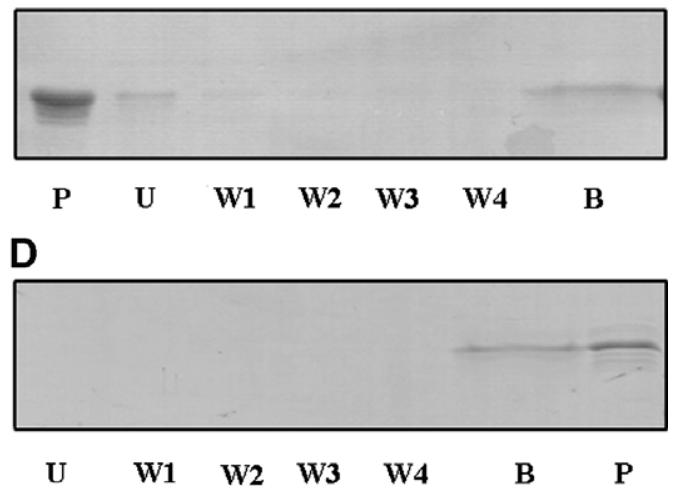

Fig. 5. Binding of LK-CBM3 (A), peptide-1-LK-CBM3 (B), peptide-3-LK-CBM3 (C) and PMAP-23-LK-CBM3 (D) to Avicel. Lanes: P, purified protein used in the experiment; U, unbound protein; W1, W2, W3 and W4, wash fractions; B, bound protein.

range at all protein concentrations (LK-CBM3 and BSA) and had no variation when compared with the numbers of CFU following incubation with Buffer A. Therefore, the results suggest that LK-CBM3 did not affect the number of existing bacteria, confirming that this CBM does not present an antibacterial activity, in contrast to what has been described for C-type lectins $[19,20]$. This observation is not particularly surprising in light of our present knowledge on the structure of Type A CBMs. It is well established that $\mathrm{CtCBM} 3$ has a ligand binding specificity restricted for crystalline cellulose. In addition, its planar binding surface is not effective for interacting with individual carbohydrate chains that are usually present on

Table 3

Antimicrobial activity of LK-CBM3

\begin{tabular}{lll}
\hline $\begin{array}{l}\text { Protein concentration } \\
(\mathrm{mg} / \mathrm{mL})\end{array}$ & Proteins & \\
\cline { 2 - 3 } & LK-CBM3 & BSA \\
& $\left(\times 10^{2} \mathrm{CFU} / \mathrm{mL}\right)$ & $\left(\times 10^{2} \mathrm{CFU} / \mathrm{mL}\right)$ \\
\hline 0.1 & 7 & 4 \\
1 & 7 & 9 \\
2 & 3 & 9 \\
\hline
\end{tabular}

Escherichia coli XL10 Gold was incubated with LK-CBM3 and BSA at three different concentrations and then plated onto LB agar plates. CFU/ $\mathrm{mL}$ were calculated after a $16 \mathrm{~h}$ incubation at $37^{\circ} \mathrm{C}$. The number of CFU/ $\mathrm{mL}$ for the experiment using exclusively buffer was $8 \times 10^{2}$. The values are average of three replicates.

Table 4

Interaction of LK-CBM3 and BSA with E. coli XL10 Gold

\begin{tabular}{lllll}
\hline Initial protein $(\mathrm{mg} / \mathrm{mL})$ & \multicolumn{4}{l}{ Unbound protein $(\mathrm{mg} / \mathrm{mL})$} \\
\cline { 2 - 5 } & $\mathrm{A}$ & $\mathrm{B}$ & $\mathrm{C}$ & $\mathrm{D}$ \\
\hline 0.1 & 0.1 & 0.1 & 0.1 & 0.1 \\
1 & 0.8 & 0.8 & 0.7 & 0.7 \\
2 & 1.2 & 1.2 & 1.2 & 1.2 \\
\hline
\end{tabular}

LK-CBM3 and BSA were incubated with E. coli XL10 Gold and cell bound protein evaluated by measuring protein concentration on the supernatant. A, E. coli with LK-CBM3; B, Buffer A with LK-CBM3; C, E. coli with BSA and D, Buffer A with BSA. the microorganisms' surface glycoproteins, as lectins do. Therefore, structural constrains would preclude the interaction of the family $3 \mathrm{CBM}$ with the bacterial cell surface. To confirm the inability of CBM3 to interact with the bacterial surface, LK-CBM3 and BSA were incubated with $E$. coli cells and bound protein was detected following cell centrifugation through the measuring of protein concentration in the supernatant. The data, presented in Table 4, confirms that the two proteins have no capacity to attach to the bacteria surface since the concentration of LK-CBM3 recovered by centrifugation after incubation with bacteria equals the one recovered after the same incubation with Buffer $\mathrm{A}$, for all initial protein concentrations $(0.1 \mathrm{mg} / \mathrm{mL}, 1 \mathrm{mg} / \mathrm{mL}$ and $2 \mathrm{mg} / \mathrm{mL})$. A similar result was observed for BSA incubation with $E$. coli XL10 Gold and Buffer A (columns C and D from Table 4). Although a small quantity of protein was lost from the initial concentration (for the protein concentrations of $1 \mathrm{mg} / \mathrm{mL}$ and $2 \mathrm{mg} / \mathrm{mL}$ ), this was probably due to protein precipitation during the assays as it was also observed for the incubation with Buffer A. The supernatants used for protein quantitations were also analyzed by SDS-PAGE. The data, presented in Fig. 6, confirmed that lack of binding was not associated with LK-CBM3 (lanes 1-3) and BSA (lanes 4-6) proteolytic degradation.

\section{Conclusions}

Here four AMPs were cloned and expressed in fusion with a family $3 \mathrm{CBM}$ of $C$. thermocellum cellulosome. Expression occurred in the soluble form for three recombinants and protocols for purifying the recombinant proteins by IMAC were developed. $\mathrm{Ct}$ CBM3 does not present detectable antimicrobial activity against E. coli XL10 Gold. Therefore, CBM3 is a good candidate polypeptide to direct binding of AMPs to cellulosic supports. Data presented here confirm that the fusion recombinants are now ready for further studies to measure and characterize their antimicrobial properties. Here it was shown that CBM3 may be attached to a non-related protein retaining its 


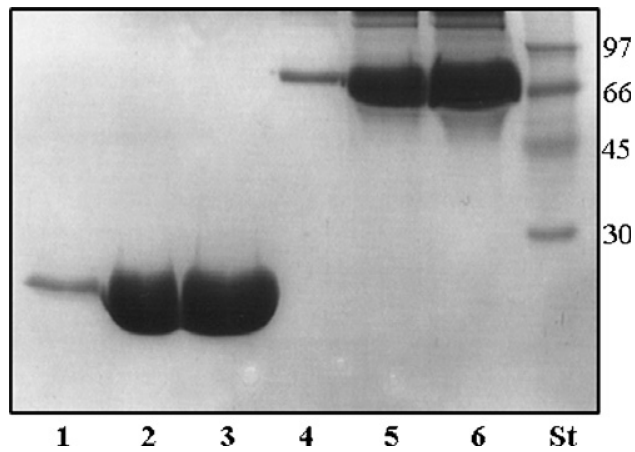

Fig. 6. Binding of LK-CBM3 and BSA into E. coli XL10 Gold as judged by SDS $14 \%$ acrylamide gel analysis. Lanes: 1 , LK-CBM3 $0.1 \mathrm{mg} / \mathrm{mL} ; 2$, LK-CBM3 $1 \mathrm{mg} / \mathrm{mL} ; 3$, LK-CBM3 $2 \mathrm{mg} / \mathrm{mL} ; 4$, BSA $0.1 \mathrm{mg} / \mathrm{mL} ; 5$, BSA $1 \mathrm{mg} / \mathrm{mL} ; 6$, BSA $2 \mathrm{mg} / \mathrm{mL}$, St, molecular mass protein standards.

intrinsic biological activity [11]. It has also been confirmed that AMPs produced in E. coli fused to a CBM maintained their properties after purification and separation from the fusion partner [18]. Therefore, the perspectives that the fusion proteins obtained in this work can display intrinsic antimicrobial activity are good and it is anticipated that their antimicrobial potency should be comparable to the AMPs expressed individually. Further studies will proceed in the future aiming at quantifying the antimicrobial properties of the proteins reported here, both in solution or fixed into insoluble surfaces.

\section{Acknowledgments}

This work was supported by the individual Grant SFRH/BD/16731/2004 (to C.G.) from Fundação para a Ciência e a Tecnologia (Portugal). We wish to acknowledge the Protein Characterization and Mass Spectrometry Laboratory at Instituto de Tecnologia Química e Biológica, Universidade Nova de Lisboa, Oeiras, Portugal, for providing mass spectrometry data on the recombinant proteins.

\section{References}

[1] J.H. Kang, S.Y. Shin, S.Y. Jang, K.L. Kim, K.-S. Hahm, Effects of tryptophan residues of porcine myeloid antibacterial peptide PMAP23 on antibiotic activity, Biochem. Biophys. Res. Commun. 264 (1999) 281-286.

[2] D.G. Lee, P.I. Kim, Y. Park, E.-R. Woo, J.S. Choi, C.-H. Choi, K.-S, Hahm, Design of novel peptide analogs with potent fungicidal activity, based on PMAP-23 antimicrobial peptide isolated from porcine myeloid, Biochem. Biophys. Res. Commun. 293 (2002) 231238.

[3] L. Peng, Z. Xu, X. Fang, F. Wang, P. Cen, High-level expression of soluble human $\beta$-defensin-2 in Escherichia coli, Process Biochem. 39 (2004) 2199-2205.
[4] Y.-H. Yang, G.-G. Zheng, G. Li, X.-J. Zhang, Z.-Y. Cao, Q. Rao, K.-F. Wu, Expression of bioactive recombinant GSLL-39, a variant of human antimicrobial peptide LL-37, in Escherichia coli, Protein Expr. Purif. 37 (2004) 229-235.

[5] I. Čipáková, J. Gašperík, E. Hostinová, Expression and purification of human antimicrobial peptide, dermcidin, in Escherichia coli, Protein Expr. Purif. 45 (2006) 269-274.

[6] Z. Xu, L. Peng, Z. Zhong, X. Fang, P. Cen, High-level expression of a soluble functional antimicrobial peptide, human $\beta$-defensin 2 , in Escherichia coli, Biotechnol. Prog. 22 (2006) 382-386.

[7] J.-Y. Moon, K.A. Henzler-Wildman, A. Ramamoorthy, Expression and purification of a recombinant LL-37 from Escherichia coli, Biochim. Biophys. Acta 1711 (2006) 1351-1358.

[8] X. Xu, F. Jin, X. Yu, S. Ji, J. Wang, H. Cheng, C. Wang, W. Zhang, Expression and purification of a recombinant antibacterial peptide, cecropin, from Escherichia coli, Protein Expr. Purif. 53 (2007) 293-301.

[9] Q. Wei, Y.S. Kim, J.H. Seo, W.S. Jang, I.H. Lee, H.J. Cha, Facilitation of expression and purification of an antimicrobial peptide by fusion with baculoviral polyhedrin in Escherichia coli, Appl. Environ. Microbiol. 71 (2005) 5038-5043.

[10] A.B. Boraston, D.N. Bolam, H.J. Gilbert, G.J. Davies, Carbohydrate-Binding Modules: fine Tuning Polysaccharide Recognition, Biochem. J. 382 (2004) 769-781.

[11] P. Tomme, A. Boraston, B. McLean, J. Kormos, A.L. Creagh, K. Sturch, N.R. Gilkes, C.A. Haynes, R.A. Warren, D.G. Kilburn, Characterization and affinity applications of cellulose-binding domains, J. Chromatogr. B 715 (1998) 283-296.

[12] J. Tormo, R. Lamed, A.J. Chirino, E. Morag, E.A. Bayer, Y. Shoham, T.A. Steitz, Crystal structure of a bacterial family-III cellulose binding domain: a general mechanism for attachment to cellulose, EMBO J. 15 (1996) 5739-5751.

[13] M. Zanetti, P. Storici, A. Tossi, M. Scocchi, R. Gennaro, Molecular Cloning and Chemical Synthesis of a Novel Antibacterial Peptide Derived from Pig Myeloid Cells, J. Biol. Chem. 269 (1994) 7855-7858.

[14] C. Morassutti, F. De Amicis, A. Bandiera, S. Marchetti, Expression of SMAP-23 cathelicidin-like peptide in bacterial cells by inteinmediated system, Protein Expr. Purif. 39 (2005) 160-168.

[15] M.M. Bradford, A rapid and sensitive method for the quantitation of protein utilizing the principles of protein-dye binding, Anal. Biochem. 72 (1976) 248-254.

[16] S.E. Blondelle, R.A. Houghten, Design of model amphipathic peptides having potent antimicrobial activities, Biochemistry 31 (1992) 12688-12694.

[17] S.L. Haynie, G.A. Crum, B.A. Doele, Antimicrobial activities of amphiphilic peptides covalently bonded to a water-insoluble resin, Antimicrob. Agents Chemother. 39 (1995) 301-307.

[18] M. Klocke, K. Mundt, F. Idler, S. Jung, J.E. Backhausen, Heterologous expression of enterocin A, a bacteriocin from Enterococcus faecium, fused to a cellulose-binding domain in Escherichia coli results in a functional protein with inhibitory activity against Listeria, Appl. Microbiol. Biotechnol. 67 (2005) 532-538.

[19] H.L. Cash, C.V. Whitham, C.L. Behrendt, L.V. Hooper, Symbiotic bacteria direct expression of an intestinal bactericidal lectin, Science 313 (2006) 1126-1130.

[20] Y.-D. Sun, L.-D. Fu, Y.-P. Jia, X.-J. Du, Q. Wang, Y.-H. Wang, X.-F. Zhao, X.-Q. Yu, J.-X. Wang, A hepatopancreas-specific C-type lectin from the Chinese shrimp Fenneropenaeus chinensis exhibits antimicrobial activity, Mol. Immunol. 45 (2008) 348-361.

[21] E.P. McGreal, L. Martinez-Pomares, S. Gordon, Divergent roles for C-type lectins expressed by cells of the innate immune system, Mol. Immunol. 41 (2004) 1109-1121. 